\title{
A Criação do Crédito Fiscal e suas Condições (*)
}

\author{
Adelmar Ferreira
}

\section{I - ELEMENTOS DA CRIAÇÃo DO CRÉDito FISCAL}

A CRIAÇÃo do crêdito fiscal ou seja a constituição do direito do Estado à percepção do tributo, depende de quatro elementos:

1. lei ordinária que determine e qualifique o tributo, a que JÈzE dá o nome de "lei orgânica do impôsto" $\left({ }^{1}\right)$;

$\left.2 .^{\circ}\right)$ lei orçamentária em que seja previsto e orçado anualmente o tributo criado por aquela lei ordinária;

3. ). ocorrência e exteriorização do fato gerador do tributo;

$\left.4 .^{\circ}\right)$ lançamento, baseado ou não em declaração do contribuinte.

Devemos considerar, ainda, outro elemento formalizador do direito do Estado, embora não essencial, pois que dispensável, se o contribuinte, em vista do lançamento, satisfaz o seu débito; é a inscrição da divida fiscal.

\section{II — LEI ORDINÁRIA}

Elemento essencial da criação do débito fiscal é a lei que estabeleça e defina o tributo, determinando o respectivo fato gerador e a pessoa obrigada ao seu pagamento.

A Constituição Federal de 1946 erige em princípio básico do direito tributário o seguinte: "Nenhum tributo será exigido ou aumentado sem que a lei o estabeleça" (art. 141, § 34). A exemplo do direito criminal, onde pontifica o principio - nullum crimen sine lege - o direito tributário também proclama principio idêntico: nutlum census sine lege. Assim, pois, a imposição do tributo pelo Estado só pode decorrer de lei permanente. A obrigação tributária é, virtualmente, ex lege: só pode nascer ou criar-se em viriude de uma lei ordinária.

\section{III — LEI ORÇAMENTÁRIA}

Lei orçamentária é o diploma legislativo que, anualmente, orça a receita e fixa a despesa do Estado, autorizando a cobrança dos tributos. Outra

(*) Monografia com Menção Honrosa.

(1) Gaston Jèze - O fato gerador do impôsto - tradução de P. Mata Machado, "Rev. Dir. Adm.", vol. II, fasc. I, página 52. 
cendição essencial para que se constitua o crédito fiscal é que o tributo, criado pela lei ordinária, seja inscrito e orçado anualmente pela lei orçamentária, que autoriza a sua arrecadação.

E' principio inscrito na Constituição Federal brasileira: "Nenhum tributo será cobrado em cada exercício sem prévia autorização orçamentária, ressalvada, porém, a tarifa aduaneira e o impôsto por motivo de guerra" (art. 14i, § 34).

Segundo OTTO MAYER, o orçamento constitui uma condição necessária para que o Govêrno possa efetuar despesas e arrecadar impostos. $\left({ }^{2}\right) \mathrm{K} E L-$ SEN adverie: "Sem o consentimento do Parlamento, o Govêrno não está autorizado a realizar despesas e arrecadar receitas, nem a executar as leis em que elas se fundam". $\left(^{3}\right)$ De GASTON Jèze são estas palavras: "O orçamento é uñ ato condição, isto é, não podem ser exigidos senão os impostos mencionados no orçamento como elmento de receita nêle autorizado". ( $\left.{ }^{4}\right)$ Francisco Campos ensina: "Do ponto de vista constitucional, o orçamento, seja qual fôr á categoria, a classe ou a definição jurídica que se lhe atribua, contèm, ao contrário do que sustenta LABAND, ordem, autorização, proibição e preceito jurídico". ( $\left(^{5}\right)$ "A Constituição exige, com efeito, que se englobem obrigatòramente na receita tôdas as rendas e suprimentos de fundos. O que aí se exige, portanto, em relação aos impostos, é que êstes sejam computados na receita não sòmente pela sua denominação técnica ou usual, mas também peía sua taxa ou tais como se acham definidos, qualitativa e quantitativamente, na lei especial da sua criação". $\left({ }^{6}\right)$

Daí se vê quăo relevante é o princípio inscrito no art. 141 , § 34 , da nossa Lei Magna, exatamente no capitulo epigrafado - Dos Direitos e Garantias Individuais - alinhado entre numerosos outros direitos concernentes à vida, à liberdade, à segurança individual e à propriedade, cuja inviolabilidade a Constituiçáo assegura aos brasileiros e aos estrangeiros. Trata-se de uma garantia de ordem financeira, de uma arma ou escudo que a Constituição põe nas mãos de cada cidadão, para protegê-lo, no dizer de Aliomar Balezero contra surprêsas insidiosas do Fisco. ( ${ }^{7}$ ) A lei ordinária estabelece e define o tributo, indicando o sujeito passivo da obrigação tributária. Não basta. E' mister que a Lei Orçamentária, a lei máxima das finanças públicas, anualmente votada, consigne, registre e estime o tributo, autorizando a sua arrecadáção no exercício financeiro a que se refere, a fim de que os contribuintes tenham conhecimento prévio do que vão pagar ao Fis-

(2) Citação de Francisco Campos, em parecer na "Rev. Dir. Adm., v. 14, pági-

(3) Idem, idem, idem, pág. 455.

(4) Idem, idem, idem, pág. 464.

(5) Francisco Campos, "Rev, Dir. Adm.", v. 14, pág. 460.

(6) Francisco Campos, "Rev. Dir. Adm.", v. 14, pág. 460.

(7) Aliomar Baleeiro - Ulma Introdução à Ciência das Finanças, vol. I, páginas $248 / 249$. 
co, para que possam organizar o seu próprio orçamento particular, prever as sua', próprias despesas, programar a sua atividade, pré-avaliar os seus ganhos, tabelar os preços dos seus produtos, sempre a coberto de qualquer agravação tributária posterior. Não se concebe, pois, que, ante o texto claro e rígido da ConstituiçãG, possa o Fisco criar ou majorar tributos, no decorrer do exercício, sem que a lei orçamentária haja consignado a lei criadora ou agravadora e estimado a arrecadação. Opina o Prof. RuBens Gomes DE Sousa no sentido de que a lei tributária material que crie ou majore tributo inscrito e autorizado antecipadamente na Lei Orçamentária, não seria, em si mesma, inconstitucional; seria inconstitucional, entretanto, por falta de autorização orçamentária prévia (o grifo é nosso). Condena o ilustre cultor do direito fiscal a inversão da ordem legislativa. Embora vàlidamente instituido o tributo pela Lei Orçamentária, não poderá êste ser vàlidamente cobrado. $\left(^{8}\right)$ Assim, também, sustenta Francisco Campos: "o aumento da taxa de quaisquer impostos, se consentido pela Assembléia Legislativa de São Paulo posteriormente à publicação do Orçamento para 1949, não poderá ser arrecadado no ano vindouro". $\left({ }^{9}\right)$ Do mesmo sentir é o Prof. Aliomar BALEEIRO, $\left(^{10}\right)$ assim como acatados outros juristas.

Não obstante, o Egrégio Supremo Tribunal Federal vem decidindo ùltimamente de modo diverso, a saber: "O aumento do impôsto no início do exercício e previsto aquêle já em orçamento, pela forma normal, não constitui infringência do $\S 34$ do art. 141 da Constituição". (11) "Estando prèviamente autorizada no Orçamento, a lei tributária de aplicação imediata pode surgir no próprio exercício financeiro em curso". ${ }^{(12)}$ " $\mathrm{E}$ ' lícita a cobrança de majoração de tributo dentro do próprio exercício, a partir da vigência da lei que o estabelecer, desde que a arrecadação do tributo esteja genèricamente consignada na Lei de Meios" (Recurso extraordinário número 35.319 e Mandado de Segurança n. ${ }^{\circ}$ 5.742).

\section{IV - O FATO GERADOR DO TRIBUTO}

O fato gerador do tributo e sua importância - A obrigação tributária nasce da lei. A sua fomalização, todavia, depende da ocorrência de um fato: é o que se chama de "fato gerador do tributo". " $E$ ' o acontecimento, o ato ou a situação jurídica que dá nascimento à dívida fiscal" (Louis FormerY "Les Impôts en France, pág. 78). " $\mathrm{E}$ ' a fixação do acontecimento material ou do fato jurídico que torna o contribuinte devedor" (CAMILle Rosier, "L'Impôt", p. 116). E' o "fato tributável", no dizer de JARACH ou a "situação-base fiscal", na expressão de AlLORIO.

(8) Rubens Gomes de Sousa - Estudos de Direito Tributário, p. 274.

(9) F. Campos, parecer, "Rev. D. Adm.", v. 14, p. 467.

(10) Aliomar Baleeiro, obra citada, v. I, p. 248/249.

(11) "R. Dir. Adm", v. 273, p. 832; v. 51, p. 104.

(12) "Rev. Dir. Adm.", v. 52, pág. 331. 
A conceituação do "fato gerador" do tributo é de importância capital na criação da obrigação fiscal, porque dela depende a verificação do direito do Fisco de proceder ao lançamento e exigir o tributo. Pela definição legal do "fato gerador" é que se pode determinar se a incidência ou imposição de tal ou qual tributo é cabivel ou não. Da conceituação do "fato gerador" é que resulta a conceituação da natureza jurídica do tributo.

O fato gerador do impôsto de consumo - Traço característico do impôsto de consumo é a sua incidência sôbre a circulação das riquezas, atingindo a renda do contribuinte no momento de ocorrência do fato econômico da aquisição dos bens para serem consumidos. E', portanto, na fase do consumo ou seja na fase final da circulação das riquezas que deve, teòricamente, assentar o impôsto de que tratamos, porisso mesmo chamado "impôsto de consumo". A lei, entretanto, pode, para maior facilidade da arrecadação do tributo, recuar ou antecipar o momento da incidência, escolhendo e definindo outro momento. E' o que acontece na lei brasileira: o "fato gerador" do impôsto de consumo é, regra geral, a saida do produto da respectiva fábrica ou da repartição aduaneira, conforme os preceitos dos artigos $3 .^{\circ}, 124,124$ $\S 19^{\circ}, 145,148,155,175,207,208,423$ e 423 § único do Regulamento do Impôsto de Consumo aprovado pelo Decreto n. 45.422 , de 12 de fevereiro de 1959 .

O fato gerador do impôsto do sêlo - Disse o eminente SÁ Filho que "a vida civil e econômica, na sua complexidade, é constituída de atos numerosos, que o direito disciplina. Sôbre grande variedade dêsses atos, que se concretizam em documentos, incide o chamado impôsto do sêlo". (13) Existe, pois, da tributação do sêlo, um elemento indispensável: a concretização do ato tributável em um documento, em um papel. O impôsto do sêlo não incide sôbre o ato ou negócio. Temos aqui um principio especial que domina a leđislação do impôsto do sêlo na Itália, França. Argentina e demais paises civiliraros, sequndo o qua $c$ referito tributo está na dependência de um documento escrito que configure formalmente o ato ou contrato visado pela lei fiscal, configuração essa que, do ponto de vista econômico e jurídico, já vem delineada do direito privado. O "fato gerador" do impôsto do sêlo é, portanto, um instrumento ou documento formal que identifique um ato ou negócio iuridico e sôbre o valor dêste ato ou negócio é que será calculado o impôsto.

Exceções ao princípio da documentação escrita - Em casos especiais, para evitar ou prevenir evasão de renda ou por outro motivo relevante, a lei brasileira que rege o impôsto do sêlo federal estabelece, de modo expresso, algumas exceções, determinando a incidência do tributo ainda mesmo na ausência de documento escrito formalizador do ato ou contrato. Citam-se as seguintes:

a) - retiradas feitas em estabelecimentos bancários, independentes de contrato, além dos limites contratuais e além dos saldos depositados em con- 
ta-corrente (art. $19^{\circ}$, Nota $1^{\text {a }}$, da Tabela anexa à Consolidação das Leis do Impôsto do Sêlo, aprovada pelo Decreto $\mathrm{n}^{\circ}{ }^{\circ} 45.421$, de 12 de fevereiro de 1959);

b) - contratos verbais de arrendamento e locação, cujo sêlo deverá ser pago nas quitações (art. $39^{\circ}$, Nota $2^{a}$, da mesma Tabela);

c) - vendas, sem contrato escrito, de mercadorias a prestações, hipótese em que o sêlo deverá ser pago na segunda via dos recibos, a qual ficará arquivada em poder do vendedor, ou na ficha de lançamento ou no fólio do "Diário" da escrita do vendedor, se não houver recibo ou quando a quitação fôr passada em duplicata de fatura ou outro papel representativo da venda (art. 16, Nota 2a, da referida Tabela);

d) - contratos verbais de construção, caso em que o sêlo será exigido na segunda via das quitações (que ficará arquivada em poder do construtor) ou, não havendo quitação, na ficha do lançamento ou no fólio do "Diário" da escrita do construtor (art. 18, Nota 2a, da mesma Tabela);

e) - empréstimos em geral, quando não haja emissão de contrato ou título representativo da divida, mas apenas lançamento de contabilidade, caso em que o sêlo será pago na respectiva ficha ou no fólio do "Diário" (art. 25, Notr $1^{\text {a }}$ da Tabela);

f) - empréstimo por meio de obrigações ou debêntures, sem contrato, caso em que o sêlo por verba será pago por meio de guia em duplicata antes de começar a emissão pela entrega dos titulos ou cautelas que representem o seu valor (art. 26, Nota 1a, da Tabela);

g) - pagamento, recebimento, transferência e crédito de qualquer natureza em moeda nacional, efetuados no país a débito ou a crédito de entidades do exterior, quando constante de lançamento da contabilidade, caso em que o sêlo proporcional será pago pelo creditador ou debitador, em ficha do respectivo lançamento (art. 35 , Nota $2^{a}$, da Tabela);

h) - recebimentos superiores a $\mathrm{Cr} \$ 100,00$, feitos por estabelecimentos bancários, caso em que o sêlo será inutilizado na ficha de caixa ou na ficha de lançamento (art. 39, Nota 3a, da Tabela);

i) -- quitação de despesa de hospedagem, hipótese em que será cobrado o sêlo de Cr\$ 3,00 de cada saida de hóspede, quando a despesa exceder de $\operatorname{Cr} \$ 100,00$, a ser pago mensalmente em livro próprio (art. 40, Nota 10?, da Tabela).

Temos para nós, entretanto, que apenas no último caso - quitação de despesas de hospedagem - é que, realmente, foge a incidência ao princípio da documentação escrita, visto que, nesta hipótese, o fato gerador do impôsto deixou de ser o documento formal (o recibo ou a quitação escrita) e passou a saida do hóspede cuja hospedagem ultrapassar de $\operatorname{Cr} \$ 100,00$. A "saída do hóspede" é que determina a obrigação fiscal.

O fato gerador do impôsto de renda é, no sistema fiscal brasileiro, a disponibilidade econômica de quantia em dinheiro ou suscetivel de avaliação em dinheiro. proveniente do capital, do trabalho ou da combinação de ambos, e compreendida na definição legal da incidência dos impostos cedulares ou 
do impôsto complementar progressivo, em se tratando de pessoas físicas, ou na definição legal de lucro tributável, em se tratando de pessoa jurídica. ${ }^{(14)}$

Examinemos o "fato gerador" do impôsto de renda nas diversas modalidades de incidência:

a) No impôsto de renda geral, de pessoa física (cedular e global), sujeito à declaração anual do contribuinte, nasce o "fato gerador", em tese, com a disponibilidade do rendimento enquadrável no âmbito de incidência de uma ou mais cédulas previstas na lei; completa-se e exterioriza-se definitivamente com a declaração do contribuinte, apresentada obrigatòriamente no prazo marcado, desde que a renda global, resultante de uma ou de diversas cédulas somadas, feitos os abatimentos autorizados pela mesma lei, ultrapasse o minimo de isenção legal. $\left({ }^{15}\right)$.

b) No impôsto de renda de pessoas jurídicas surge o fato gerador, em tese, com o balanço anual em que fica determinado o lucro decorrente das operações realizadas no ano-base; exterioriza-se com a declaração de rendimentos apresentada obrigatòriamente no prazo fixado.

c) Nos casos de impôsto de renda arrecadado na fonte, o "Fato gerador" surge e exterioriza-se no instante em que o rendimento é pôsto à disposição do respectivo titular. Daí porque os órgãos competentes do Ministério da Fazenda têm decidido que: - "tratando-se de arrecadação na fonte, o fato gerador verifica-se na data da deliberação tomada pela Assembléia..-Geral da sociedade anônima, do aumento do capital, mediante utilização das reservas" (decisões da Divisão do Impôsto de Renda publicada na Revista Fiscal de 1952/16; 1952/19; 1952/104 I; 1952/405; acórdãos do 1.ำ Conselho de Contribuintes: $37.903,37.905 ; 39.485,41.500,42.246$ e outros); ou no momento do pagamento, crédito, etc., nos casos dos arts. 97 e 98 do Regulamento (decisão da D.I.R. na Rev. Fiscal de 1952/945; acórdãos $37.442,37.978$ e 38.018 , do $10^{\circ}$ C.C. ); ou, ainda, no ato de ser lavrado o instrumento de compra e venda, no caso de impôsto de renda sôbre lucro imobiliário.

d) No impôsto de renda cobrado como adicional chamado de "proteção às familias numerosas" (decreto-lei n. 3.200, de 1941), em que não se adota o sistema de ano-base, o fato gerador" é a existência de renda tributável, percebida por contribuinte (pessoa física), constante de sua declaração, contribuinte êsse que, até 30 de abril de cada ano, seja maior de 25 anos, solteiro, casado ou viúvo sem filhos, ou maior do 45 anos com um só filho (decisões da D.I.R. na Rev. Fiscal de 1942/81 A; de 1944/250; de 1944/91: de 1954/575; acórdão n. ${ }^{\circ} 16.061$ do $10^{\circ}$ C.C. e ac. n. ${ }^{9} 50$ da novel 2: Câmara do $10^{\circ}$ Conselho de Contribuintes).

O fato gerador dos tributos aduaneiros é a passagem dos produtos pela linha de fronteira do pais. Desta definição decorre que o sujeito passivo da

(14) Prof. Gomes DE SousA, obra citada, p. 174.

(15) Idem, p. 176. 
obrigação tributária aduaneira é a pessoa que se encontre em relação de causa e efeito com o respectivo fato gerador, isto é, a pessoa que ocasiona a passagem da mercadoria pela fronteira ou linha aduaneira. $\left.{ }^{(16}\right)$

O problema da bi-tributação - Para compreender -se bem a relevância da conceituação do "fato gerador", basta lembrar que dela decorre, muitas vêzes, a solução definitiva de sérios problemas de bi-tributação, partindo-se do pressuposto de que a incidência tributária não acarreta bi-tributação quando os atos atingidos têm fatos geradores diferentes ou distintos. Vejamos alguns exemplos:

a) Dos produtos vindos do estrangeiro cobram-se dois impostos simultâneamente: o aduaneiro e o de consumo. Não há, contudo, bi-tributação, porque o fato gerador do primeiro é a passagem da mercadoria pelo linha de fronteira e o do segundo é o "consumo", certamente antecipado pela lei o momento da incidência;

b) O impôsto de consumo difere do impôsto estadual de produção, porque êste incide sôbre "o complexo das operações tendentes a transformar e aperfeiçoar econômicamente um determinado produto" (definição do Sup. Tribunal Federal) e aquêle sôbre o "consumo";

c) Entre o impôsto de consumo e o de vendas mercantis não há bi-tributação: o fato gerador dêste último é a operação de venda do produto;

d) O impôsto do sêlo federal não se confunde com o impôsto estadual de vendas e consignações: êste assenta sôbre a operação de venda, tantas vêzes quantas vendas se realizarem: aquêle sôbre o documento escrito que encerra "atos ou contratos";

e) Das fotocópias fornecidas por Estado-membro da Federação, êste pode cobrar impôsto pela sua expedição, impôsto êsse que não colide com o sêlo de autenticação exigido pela União (art. $4 .^{\circ}$ da Tabela anexa à vigente Consolidação das Leis do Impôsto do Sêlo), porque diferentes e distintos são os fatos geradores de um e outro tributo "Revista dos Tribunais", vol.. 272 p. 797);

f) Não é inconstitucional o impôsto do sêlo criado pelo Estado de São Paulo, para a expedição do certificado de propriedade de automóvel, eis que nãi) ocorre bi-tributação, face ao sêlo federal, uma vez que diferentes são os fatos geradores respectivos, segundo proclamou o Supremo Tribunal Federal (jornal "O Estado de São Paulo", de 29-7-1958).

\section{V - EXTERIORIZAÇÃo DO FATO GERADOR}

A verificação do "fato gerador" dos tributos é feita em face da sua exteriorização, isto é, da ocorrência de atos ou fatos que o tornem realizado. Diz o Prof. Rubens Gomes de Sousa que "o nascimento da obrigação tri-

(16) Prof. GoMes DE SousA, obra citada, p. 64. 
butária individual se processa em três fases, que, normalmente, são sucessivas (podendo, entretanto, tôdas ou algumas delas ser simultâneas):

a) nascimento da obrigação tributária em tese (fato gerador);

b) exteriorização do fato gerador (declaração);

c) nascimento da obrigação tributária em espécie (lançamento). JÈze, por sua vez, esclarece que "muitas vêzes acontece consistir o fato gerador em um conjunto de fatos. $E^{\prime}$ ' a reunião de todos êsses fatos que constitui o fato gerador do impôsto". (18)

Realmente, acontece que, em certos tributos, a exteriorização do "fato gerador" é determinada pela ocorrência de dois ou mais fatos ou atos. Vejamos :

$10^{\circ}$ Impôsto sôbre a renda - O "fato gerador" é, como vimos, a disponibilidade econômica de uma importância em dinheiro. Contudo, nas hipóteses de impôsto de renda de pessoa física (cedular e global) e de pessoa jurídica (sôbre o lucro liquido apurado em balanço), a exteriorização do "fato gerador" ocorre, por imperativo legal, com a declaração de rendimentos que o contribuinte é obrigado a apresentar ao Fisco em prazo determinado, à vista da qual será feito o lançamento.

2.ं) Impôsto do sêlo:

a) nos têrmos do art. $40, \S 1 .{ }^{\circ}$, das Normas Gerais, da vigente Consolidação das Leis do Impôsto do Sêlo, se o valor dos papéis não puder ser determinado inicialmente, por depender de apuração posterior, a cobrança do sêlo se fará por estimativa de contribuinte; registrado o documento na repartição arrecadadora depois de pago o impôsto com base na estimativa (art. $40, \S 2 .^{\circ}$ ), será o restante do tributo, calculado sôbre o valor das operações de cada dois anos, pago bienalmente mediante a reapresentação obrigatória do referido documento $\left(\S 2 . .^{\circ}, b\right.$, e $\left.\S 3 .^{\circ}\right)$;

b) nus papéis em que houver obrigações de prestações cujo total não se cieclare, o sêlo incidirá inicialmente sôbre a importância relativa a dois anos e, expirado êste prazo, se repetirá anualmente, dentro dos oito primeiros dias de cada ano, até que terminem as prestações (art. 46, N.G.G., e Nota $1^{\text {a }}$ ao art. $3 .^{\circ}$ da Tabela anexa);

c) nos papéis em que se estipularem juros e comissões a prazo indeterminado, o sêlo será pago inicialmente sôbre o valor do principal e, ao fim de cada semestre de vigência, sôbre a importância de juros e comissões (artigo 17 das N.G.G.);

d) nas retiradas feitas em estabelecimentos bancários (abertura de créta-corrente, o sêlo será devido em cada semestre do ano, sôbre o maior saldo devedor, acrescido dos juros e comissões, e pago nos oito primeiros dias do semestre seguinte (Nota $2^{a}$ ao art. $1 .^{\circ}$ da Tabela)). Vemos, assim, nesses

(17) Prof. Rubens Gomes De SousA, obra citada, págs. 172/173.

(18) Gaston Jèze, obra citada, págs. 50/51. 
casos, que a exigência do sêlo se processa em duas ou mais fases: $1^{\text {a }}$ a da estimativa ou a da fixação das prestações de dois anos ou do valor do principal; e $2^{\text {a }}$ a da reapresentação do papel ou a da expiração do prazo de dois anos ou do semestre. O fato gerador do tributo é a criação do papel que encerre ato ou contrato visado pela lei fiscal. A sua exteriorização, porém. é que se verifica em fases distintas: no momento da criação, emissão ou assinatura do papel, e nos momentos de cada reapresentação do mesmo documento para pagamento do restante do tributo devido ou após cada expiração dos prazos de dois anos e de seis meses fixados pelos artigos 47 e 48 citados.

\section{Impôsto de consumo:}

a) produtos transformados, montados, beneficiados ou reacondicionados (art. 5. das N.G.G. do Reg. aprovado pelo Decreto n. ${ }^{\circ} 45.422$, de 1959) ficarão sujeitos a novo impôsto (integral ou com dedução do que fôra pago inicialmente), correspondente à nova classificação, ao sairem do estabelecimento transformador, beneficiador, montador ou reacondicionador (artigos $148,223,225,226$ e outros do citado Regulamento);

b) produtos vendidos por filiais e outros estabelecimentos comerciais, por preços superiores aos cobrados inicialmente pela fábrica, ficarão sujeitos ao pagamento das diferenças de impôsto que se verificarem (arts. 146, 207 e outros das N.G.G. do mesmo Reg.);

c) Jóias e outros produtos previstos pela alinea XXVI, Tab. "B", do citado Regulamento: pago o impôsto inicialmente com base no preço de importação ou do fabricante, serão as diferenças sucessivas entre os preços de aquisição e revenda ao consumidor pagos pelo importador, beneficiador, reformador, transformador ou comerciante (art. 175 das N.G.G.);

d) produtos de procedência estrangeira:

I - inicialmente, será pago o impôsto com base no preço de importação, acrescido das despesas de frete, etc.;

II - posteriormente, os importadores ou arrematantes pagarão o impôsto com base nas vendas que efetuarem, realizadas em cada quinzena, deduzido o impôsto pago inicialmente (art. 154 das N.G.G.). Atendamos bem para que, nas hipóteses supra referidas, o "fato gerador" do impôsto de consumo surge no momento da saída dos produtos das respectivas fábricas ou das estações aduaneiras, mas exterioriza-se em fases diferentes: por ocasião daquela saída e por ocasião das saídas dos mesmos produtos dos estabelecimentos transformadores, beneficiadores, importadores, revendedores ou comerciantes.

Assim, pois, devemos repetir, para melhor compreensão dêste assunto:

$1 .^{\circ}$ a fato gerador da obrigação tributária pode ocorrer e exteriorizar-se imediatamente ou seja em atos simultâneos (nascimento em tese $e$ declaração); mas,

$\left.2 .^{\circ}\right)$ pode ocorrer e revelar-se exteriormente, ou, melhor dizendo, completar-se, integrar-se em fases ou periodos sucessivos e diterentes, fixados 
pela lei para pagamento do tributo. O "fato gerador" será completo e exteriorizado em cada fase ou período de pagamento do tributo, apto a produzir os seus efeitos jurídicos, quando ocorrido cada um dos atos determinantes das fases ou períodos de satisfação do tributo. Tenhamos em consideração que o aperfeiçoamento e a execução do direito do Fisco, que constituem o lançamento, sòmente se verifica com a ocorrência de todos os elementos da obrigação fiscal inclusive a valorização da matéria tributável; e que essa valorização - uma das condições legais da imposição fiscal - pode ser feita, por fôrça da própria lei, periòdicamente, posteriormente ao nascimento do fato gerador em tese, resultando daí a dilatação da fase de exteriorização do fato gerador, ou seja o desdobramento dessa exteriorização em duas ou mais fases. Convenhamos em que o "fato gerador" do impôsto de consumo, na sistemática da lei brasileira, é um só: - a saída do produto da fábrica ou da repartição aduaneira. Este evento é que determina, em tese, o direito do Fisco ao tributo. Mas, tal "fato gerador" pode ficar na dependência, total ou parcial, de novos atos ou fatos que completam ou concretizam definitivamente, com a valorização do ato econômico, aquêle primitivo ou inicial fato gerador. A nosso ver, o legislador nos casos citados, não quis criar "fato gerador" novo, independente ou autônomo, que seria, então, a "venda" do produto pelo importador, beneficiador ou outros contribuintes visados pela lei. Não se trata, nos mesmos casos, de segundo e novo "fato gerador". mas de exteriorização ou concretização parcial do verdadeiro e único "fato gerador", já então na sua segunda fase de arrecadação do tributo, quando se verifica a determinação final do preço de venda do produto no mercado interno do país, que é a verdadeira base da incidência.

\section{VI - EFEITOS DA OCORRENCIA E EXTERIORIZAÇÃO DO FATO GERADOR DO TRIBUTO}

principal efeito da ocorrência e exteriorização do fato gerador do tributo é a constituição de um direito adquirido pelo Fisco e outro pelo contribuinte:

1. $\left.{ }^{\circ}\right)$ pelo Fisco, o direito de praticar os atos administrativos tendentes a fazer nascer o crédito fiscal, ou seja o lançamento;

$2^{\circ}$ ) pelo contribuinte, o direito a que o crédito fiscal seja criado (ou não seja criado) sòmente conforme tôdas as condições ou todos os elementos existentes na data do fato gerador (matéria tributável e tarifa do tributo. $\left({ }^{19}\right)$

Êsse direito do contribuinte manifesta sua influência nas seguintes questões:

1") A avaliação da matéria tributável deve ser feita na base do seu valor à data do fato gerador. Exemplo: a valorização ou desvalorização do

(19) Prof. Rubens Gomes de Sousa: Estudos de Direito Tributário, p. 169; Gaston Jèze: O fato gerador do impôsto - "Rev. Dir. Adm". v. II, fasc. I, p. 51. 
imóvel posterior ao fato gerador do impôsto de transmissão, não tem efeito quanto ao cálculo do tributo. $\left({ }^{20}\right)$ Esclarece Jèze: "Para liquidar o montante da divida de tal pessoa, a título de tal impôsto, para fixar o valor da matéria tributável, é preciso transportar-se ao dia do fato gerador do impôsto. Se, ulteriormente, êsse valor aumenta ou diminui, isso não tem importância para a liquidação da divida do impôsto". $\left({ }^{21}\right)$.

$2^{3}$ ) As condições pessoais do contribuinte, que possam afetar o montante da tributação (ou o próprio nascimento do crédito, nos casos de isenções pessoais) são as existentes à data do fato gerador: as modificações posteriores (nascimento ou falecimento de filhos, diferenças de idade, etc.) não influirão na fixação dos elementos do débito fiscal. $\left({ }^{22}\right)$.

3a) O tributo será devido de acôrdo com a aliquota ou tarifa vigente à data do fato gerador: as posteriores elevações ou reduções não terão efeito após a ocorrência e exteriorização daquele fato gerador. $\left({ }^{23}\right)$ Ensina GASTON JÈze: "Para liquidar o montante da dívida fiscal de tal individuo a título de tal impôsto, será aplicada a tarifa de impôsto fixada pela lei vigente no dia do fato gerador. Se ulteriormente veio a ser a tarifa aumentada ou diminuida, pouco importa. Êsse acréscimo ou essa diminuição da tarifa não atinge os fatos geradores precedentes". $\left({ }^{24}\right)$

$\left.49^{\circ}\right)$ A revogação do tributo ocorrida posteriormente à exteriorização do fato gerador, não acarreta exoneração do mesmo tributo. $\left({ }^{25}\right)$ No mesmo sentido diz GAston JÈzE: "Se uma lei suprime um impôsto, essa supressão não produz efeito sôbre os fatos geradores anteriores". $\left({ }^{26}\right)$

5.9) O fato gerador marca o início do prazo de prescrição do direito de o Fisco criar o débito fiscal ou seja efetuar o lançamento. $\left({ }^{27}\right)$ Convérn, neste passo, distinguir:

a) a prescrição do direito de lançamento: $e$

b) a prescrição do direito de cobrar a dívida já lançada. No caso "a", a prescrição começa na data do fato gerador do tributo; no caso "b", na data do lançamento efetuado. ${ }^{(28)}$

\section{VII - O FATO GERADOR DO TRIBUTO EM FACE DA TEORIA DO DIREITO ADQUIRIDO}

A Constituição Federal Brasileira de 1946 proclama o respeito ao direito aḋquirido. nêstes têrmos: "Art. $141, \S 30^{\circ}-A$ lei não prejudicará o direito erdquirido, o ato juridico perfeito e a coisa julgada". Justifica Lassale,

(20) R. GOMES DE SousA - obra citada, p. 168.

(21) Gaston Jèze, ob. citada, p. 54/55.

(22) Gomes DE Sousa, idem, p. 169.

(23) Idem, idem, p. 169.

(24) G. Jèze, ob. cit., p. 55.

(25) G. Sousa, idem, p. 169.

(26) G. JÈzE, p. 55.

(27) Gomes DE Sousa, ob. citada, p. 169; G. Jèze, id॰m, p. 55.

(28) Prof. Rubens Gomes DE SousA, obra citada, p. 169; e G. JÈze, obra citada, página 55 . 
com precisão: "Aquêle que agiu livremente, conhecendo a lei vigente, e de conformidade com ela adquiriu um direito, sujeitando-se a tôdas as conseqüências do seu ato nos têrmos da mesma lei, por confiar na ordem jurídica existente, não pode, sem violência, ser, por disposição de uma lei nova, privado dêsse direito adquirido". E conclui: "O efeito retroativo da lei. neste caso, seria uma afronta à personalidade do indivíduo, desrespeitando a vontade por êle manifestada, de acôrdo com a lei que conhecia". $\left({ }^{29}\right)$

princípio constitucional do respeito ao direito adquirido estenderse, também, ao direito fiscal: revelada e concretizada a obrigação tributária, relo nascimento e exteriorização do fato gerador do tributo, surge, para o Fisco, o direito de proceder ao lançamento e cobrar o mesmo tributo; e, para o contribuinte, o direito de pagar ou não pagar certo tributo que o atinja, na forma, no tempo, nas condições e conforme todos os elementos existentes na data do fato gerador, porque nesta data é que êle, contribuinte, contrai com o Fisco a obrigação tributária.

Alguns juristas negam a existência de direito adquirido em matéria tributária. TROTABAS, por exemplo, afirma que o contribuinte não tem direito adquirido em matéria de impôsto, porque, sendo êste u'a manifestação de soberania do poder estatal, êsse poder compreende a possibilidade de alterar a situação objetiva legal, a cada passo. $\left({ }^{30}\right)$ DE RugGIERo, por sua vez: sustenta que, nas matérias em que predominam o interêsse do Estado e a ordem públicá, o fato já verificado deve ser governado pela lei nova, de aplicação imediata. ( $\left.{ }^{31}\right)$ Tal doutrina, entretanto, não prevalece em nossa Pátria. O Prof. Rubens Gomes DE Sousa ensina: "Na aplicação do tributo em cada caso particular, as relações que surgem entre o Estado e o contribuinte não são mais relações de soberania, mas relações de direito, relações jurídicas, isto é, regidas pela lei, que se aplica igualmente a ambas as partes, uma vez que o Estado não é superior ao seu próprio direito". ( $\left.{ }^{32}\right)$ E o Prof. UlhôA CAnto declara: "Essa concepção não se reajusta à realidade do Estado de Direito, que é a base filosófica das organizações contemporâneas, porque o próprio Fisco, embora seja êle o Estado, não pode fugir à regra que, pelo seu ramo legislativo, notadamente o constituinte, estabeleceu". ( $\left.{ }^{33}\right)$

O fato gerador do tributo determina, por conseguinte, um direito adquirido, quer para o Fisco, quer para o contribuinte, porque é um fato jurídico capaz, na expressão de GABBA, de produzir aquêle direito em virtude da lei vigente ao tempo em que se verificou, e que entrou imediatamente no patrimônio do seu titular. $\left({ }^{34}\right)$

(29) LasSale, Théorie Syst des Droits Acquis, trad. francêsa, v. I, cap. 2, páginas 65 e seguintes. pág. 424 .

(31) Roberto de Ruggiero, Instituições de Direito Civil, vol. I, p. 443/444.

(32) Gomes DE Sousa, Curso de Int. ao Dir. Trib., Rev. de Estudos Fiscais. 1948, n.* 12, pág. $497 / 498$.

(33) Ulloôa Canto, ob. cit., p. 424.

(34) GabBa, citado pelo Prof. Reinaldo Porchat, Dir. Romano, p. 454. 
Tempus Regit Actum - Pôe-se de manifesto, assim, que, no direito fiscal, domina o principio Tempus Regit Actum. E' a lei substantiva vigente ao tempo em que surgiu e se exteriorizou o fato gerador do tributo que deve ser aplicada na criação do débito fiscal. Para que seja fixada a matéria tributável, individuado o contribuinte, determinada a alíquota do tributo e verificadas tôdas as condições e elementos da obrigação fiscal, deve ser aplicada a lei tributária material em vigor na data em que ocorreu aquêle fato gerador.

Os efeitos, em geral, que derivam das obrigações, ensina RuGGiero. são governados pela lei vigente ao tempo em que o vinculo se constituiu. ( ${ }^{35}$ ) Ora, a obrigação tributária é uma obrigação e não difere substancialmente da obrigação de direito privado, embora pertença ao Direito Público, sob cujo ângulo é encarada e estudada. Daí decorrem, no terreno do direito fiscal, as seguintes conseqüências:

a) a lei nova, que aumenta, reduz ou extingue tributos, não se aplica a obrigaçōes fiscais contraidas e reveladas pelo "fato gerador" no domínio da lei antiga;

b) a alíquota do tributo é aquela em vigor no momento em que se realizou o "fato gerador".

E neste passo, indagamos: como se deve considerar o "fato gerador"? Siraplesmente no seu surgimento em tese? Ou na sua integração efetiva, resultante da ocorrência de atos ou fatos posteriores que a lei exige para criação do crédito fiscal?

Temos sustentado neste trabalho que o "fato gerador" do tributo produz os seus efeitos quando exteriorizado por forma, atos ou fatos que a lei prescreve. Não haverá problema se a exteriorização do "fato gerador" se operar imediatamente ou simultâneamente ao seu nascimento. Por exemplo: a criação de um papel ou documento sujeito ao impôsto do sêlo; a saída de produto alcançado pelo impôsto de consumo, da fábrica ou da repartição aduaneira: a disponibilidade imediata de rendimento tributável na fonte. Nesses casos, aplicável é a lei material vigente ao tempo em que ocorrer a criação do documento, a saída do produto ou a disponibilidade do rendimento na fonte. No impôsto de renda de pessoa física ou jurídica, dependente de declaração, também não ocorrerá dúvida: aplicável é a lei ou a alíquota vigente no prazo marcado pela lei para apresentação de declaração. Êsse regime de tributação tem como base de incidência os rendimentos brutos, deduções e abatimentos relativos ao ano anterior ao exercício financeiro em que o impôsto fôr devido (artigo 22 do Regulamento) ou o lucro real verificado em balanço e demonstração da conta de lucros e perdas, referentes ao ano anterior (artigo 32 do mesmo Regulamento). A tributação, porém, obedece às alíquotas vigentes ao tempo da liquidação do impôsto, ou seja no prazo fixado pela lei para que o contribuinte apresente declaração de rendimentos. Por isso é que o 1. Conselho de Contribuintes firmou jurisprudência no sentido de que "a

(35) DE Ruggiero, obra citada, p. 191. 
lei vigente para cobrança do impôsto de renda é determinada pelo exercício financeiro em que fôr devido e não a relativa ao ano de base" (Acórdãos ?8.011, 28.570, 33.602 e outros).

Entretanto, dúvidas poderão aparecer nos diversos casos que focalizamos atrás, em que o "fato gerador" se exterioriza em duas ou mais fases, tornando-se o impôsto devido em partes, em épocas diferentes. Qual a lei ou a aliquota tributária aplicável? A que vigorava ao tempo do nascimento em tese do "fato gerador" ou da arrecadação do tributo na primeira fase? Ou a que vigorar ao tempo em que ocorrer a $2^{\text {a }}$ ou outra fase posterior da arrecadação do tributo?

Ora, já vimos que, por imperativo da lei fiscal, nos casos ventilados, nascido em tese o " fato gerador", cada realização parcial dêsse "fato gerador" determina uma obrigação fiscal. E' a própria lei fiscal, nos casos sitados, que prescreve a realização do "fato gerador" em partes ou fases e determina o direito do Fisco em cada realização parcial. Concluímos, assim, que é aplicável a lei fiscal ou a alíquota do tributo vigente ao tempo em que se realizar cada exteriorização parcial do "fato gerador". Assim,

No impôsto do sêlo - aplica-se a lei ou a aliquota vigente ao tempo em que se der a criação do instrumento sujeito ao referido tributo, na primeira fase de arrecadação (a relativa à estimativa do valor futuro das operações ou à fixação inicial das prestações de dois anos ou do valor principal); e, aplica-se a lei a aliquota vigente em cada fase posterior da arrecadação do impôsto, a saber:

a) nas reapresentações do papel por fôrça e para os efeitos do artigo 40 e seus $\S \S$ das Normas Gerais da Consolidação das Leis do impôsto do Sêlo;

b) anualmente, após expiração do prazo de dois anos, nos papéis em que houver obrigação de prestações cujo total não se declare (art. 56 das N.P.G., e nota $1^{\text {a }}$ ao art. $3 .^{\circ}$ da Tabela);

c) após cada semestre, nos papéis em quie se estipulam juros e comissões a prazo indeterminado e nas retiradas feitas em estabelecimentos bancários, quando ocorrerem as hipóteses previstas no art. $1 .^{\circ}$. Nota $1^{a}$, da mesma Tabela.

O 1. Conselho de Contribuintes decidiu, segundo os Acórdãos 16.430 e 17.171 , que, em matéria de tributação, domina o princípio da aplicabilidade da lei vigente ao tempo em que se praticou o ato tributável ou em que se tornou exigivel o impôsto ("Revista Fiscal" de 1943, decisão 792; e de 1944, dec. 114); e, pelo Acórdão 26.512 manifestou entendimento diverso, aliás aplaudido por Tito Rezende e Jaime Péricles, mas que, a nosso ver, não se ajusta à natureza jurídica do impôsto do sélo e do seu fato gerador: o de que, "havendo transações sob vigência de duas leis, aquelas deverão estar 3itjeitas às taxas de cada qual" ("Revista Fiscal" de 1949, dec. 445, e Manua! do Sêlo, $6^{\text {a }}$ edição, t. $19^{\circ}$, p. 18).

Posteriormente, porém, decidiu de modo contrário o referido $1 .^{\circ}$ Conselho, no Acórdão n..$^{9} 40.574$ : "O momento da fixação da taxa é o da assi- 
natura do papel" ("Rev. Fiscal" de 1955, dec. 252). Dêste acórdão houve recurso $€$ o Sr. Ministro da Fazenda a êle deu provimento, para restabelecer a verdadeira doutrina sôbre o assunto ("Rev. Fiscal" de 1955, doc. 252). Aliás, a mesma exegese já havia sido adotada pelo Ministro da Fazenda, quando resolveu que "desde que o regulamento prescreve que o sêlo será pago à proporção que as contas forem apresentadas, o sêlo proporcional devido é o da época da apresentação das contas, e não o do tempo em que o contrate foi celebrado" (Manual do Sêlo, de Tito Rezende e Jaime Péricles, 5. edição, pág. 130).

No impôsto de consumo - aplica-se, inicialmente, a lei fiscal ou a aliquota vigente ao tempo em que se realizar a primeira fase do "fato gerador" (a saida do produto da fábrica ou da repartição aduaneira), e, posteriormente, aplica-se a lei ou a aliquota vigente ao tempo em que se verificar cada fase de arrecadação tributária, a saber:

a) na saída do produto do estabelecimento importador;

b) na saida do produto do estabelecimento beneficiador, reformador, transformador ou revendedor, nos casos em que figuramos linhas atrás.

\section{VIII - A PRESCRIÇÃO NO DIREITO FISCAL}

O "fato gerador" do tributo, já o vimos, também produz o relevante efeito de marcar o início do prazo de prescrição do direito do Fisco de criar o débito fiscal ou seja proceder ao lançamento do contribuinte. Da mesma forma, entendemos que o "fato gerador" produz tal efeito em cada fase da sua ex+eriorização. O prazo prescricional do direito do Fisco começa a fluir, em cada fase da arrecadação do tributo, desde a data em que se realizar parcialmente o fato gerador.

A propósito dêste assunto, vamos recordar um exemplo concreto da aplicação na prática do principio ora focalizado,, mas com relação à penalidade que caberia na hipótese, ante a exteriorização parcial do "fato gerador" do impôsto do sêlo, na primeira fase da sua arrecadação. No Acórdão número 45.435. de 22-8-55, publicado no "Diário Oficial" (seção IV) de 29-1-56 e na Rev. Fiscal de 1956 , dec. 377 , o $1^{\circ}$ Conselho de Contribuintes apreciou un caso de contrato de valor não conhecido ao ser assinado, que as partes deixaram de registrar na repartição competente. Não havia sido pago o impôsto do sêlo devido pelo valor da estimativa, nem o que se tornara devido após dois biênios de vigência. O Conselho ponderou:

a) que a estimativa deveria abranger as operações realizadas antes da assinatura do contrato, uma vez que êste tivera efeito retroativo;

b) que, no tocante à primeira parte (a da estimativa), caberia a multa do art. 72 ("caput") das Normas Gerais da Lei do Sêlo em vigor, e, quanto à segunda parte (a dos biênios) teria aplicação a multa do art. $72, \S 1 .^{\circ}$ das mesmas Normas Gerais, porque esta infração era específica, independente da que ocorrera com a falta de apresentação do papel para registro prévio: 
c) que, entretanto, em relação à primeira parte (a da estimativa), prescrito se achava o direito do Fisco de impor penalidade (art. 6) das Normas Gerais), uma vez que haviam decorrido mais de cinco anos da data em que se tornou devida a primeira parcela do impôsto (a relativa à estimativa). Cnicluiu o Conselho exigindo o impôsto total e a multa do art. $72 \S 1 .^{\circ}$ das Normas Gerais, calculada sôbre o tributo devido após os biênios.

\section{IX - DO LANÇAMENTO FISCAL}

Lançamento, no sentido puramente gramatical, é o ato de lançar ou registrar em papel ou livro, algum fato. Do ponto de vista do direito fiscal, lançamento è o ato do Fisco consistente em inscrever uma pessoa física ou jurıdica no rol dos contribuintes. E' o ato pelo qual a Administração Pública constita e apura uma obrigação tributária, revelada pelo "fato gerador" do tributc, determinando o sujeito passivo dessa obrigaçäo e fixando o "quantum." do seu débito.

Devemos considcrar que o lanı̧amento não é ato jurisdicional, porque, sendo de caráter unilateral, ou seja praticado unilateralmente pela Administração Pública não há como falar em jurısdição. $\left({ }^{36}\right)$ Como ato administrativo, está sujeito a exame, revisão ou contrôle do Poder Judiciário.

U lançamento tem por finalidade declarar o efeito constitutivo do "fato gerador." do tributo, que é a criação de um débito fiscal do contribuinte. $\left.{ }^{\left({ }^{7}\right.}\right)$

O Fisco prosede ao lançanzento com ou sem o auxilio do contribuinte: à vista de declaração apresentadia espontânea ou obrigatòriamente pelo contribuintc, $0^{\circ} 1$ mesno sem a cooperaçâo dêste, através de pesquisas ou sindicância dos elemeritos constitutivos do "fato gerador", a Administração Pública determina e fixa o seu crédito fiscal. Casos há de auto-lançamento, em que o contribuinte, por si inesmo, sem intervenção do Fisco, faz o seu próprio lancamento, con o caráter condicional "si et in quantum", sujeito à revisão a aceitação do poder fiscal. (Exemplos: a selagem de um documento, a emissão de uma nota fiscal, etc.).

O lançamento, por consegtinte, náo é, rigorosamente, um ato, mas, sim, um processo. ${ }^{(38}$ ) ou seja uma série ou conjunto de atos interligados, que tem por fim precisar, em têrmos de responsabilidade e valorização, o crédito fiscal, criando o respectivo titulo a ser inscrito para cobrança da divida.

O lançamento fiscal pode, também, revestir-se da forma de auto de infração, representação os: notif́tcação, lavrado por funcionário público competente, tendo por finalidade apurar contravenção fiscal punivel pela lei.

Fases do lançamento -- $U$ processo de lançamento fiscal desenvolve-se em ciuas fases: a oficicsa e a contenciosa. Na fase oficiosa, que começa, em regra, pela exteriorização do fato gerador (a declaraçáo do contribunte),

(36) GoMes DE SousA, Estudos de Dir. Trib., pág. 41.

(37) Idem, p. 187.

(38) Gomes DE Sousa, Estudos de Dir. Trib., pág. 184. 
o Fisco procede à verificação oficial da ocorrência daquele fato gerador, valoriza quantitativa e qualitativamente o mesmo fato, aplica a sanção prevista na lei, fixa, assim, o "quantum" do débito fiscal do contribuinte, expede o aviso de lançamento, criando, destarte, o titulo formal da divida. (39)

$\mathrm{Na}$ fase contenciosa que começa com a contestação do contribuinte, por meio de defesa apresentada no prazo legal, o Fisco aprecia as razões invocadas pelo contribuinte $e$ as provas colhidas, e, por sentença de caráter administrativo, altera ou ratitica os resultados ou seja o lançamento feito na fase oficiosa, para, nestas condições, extrair e inscrever o título definitivo do seu crédito, com o qual poderá ingressar em juízo, caso o contribuinte não satisfaça antes o seu débito. Nesta fase, dita contenciosa, mas sem o caráter de contencioso administrativo, porque a decisão do Fisco é suscetivel de exame. revisão e contrôle pelo Poder Judiciário, a Administração Pública exerce, no dizer do Prof. Rubens Gomes DE SousA, uma função jurisdicional. A atividade jurisdicional ensina o emérito professor, é exercida sucessivamente por diversos órgãos. de naturezas difirentes; o sistema difere segundo as legislações positivas, mas, em síntese, ocorre o exercício da atividade jurisdicional pelos seguintes órgãos:

$1^{\circ}$ ) pela própria autoridade fiscal (reclamação);

$\left.2 .^{\circ}\right)$ por uma autoridade administrativa separada e autônoma da autoridade fiscal (recurso aos Conselhos de Contribuintes, Tribunal de Impostos e Taxas, etc.);

$\left.3 .^{\circ}\right)$ novamente pela autoridade administrativa, agindo, porém, desta vez, em caráter de autoridade hierárquica e não de autoridade fiscal (recurso ao Ministro);

$4 .^{\circ}$ ) finalmente, pela autoridade judiciária (ação de anulação de lançamento ou executivo fiscal) em seus diversos graus ou instâncias. $\left({ }^{40}\right)$

Efetivamente, a decisão administrativa não deixa de ser uma sentença, porque, embora de caráter puramente administrativa, tem o seu aspecto deliberativo ou declaratório de direito do Fisco ou do contribuinte e projeta sua eficácia e seus efeitos fora ou além do processo, se o contribuinte com ela se conforme e extingue, pelo pagamento, a sua obrigação tributária, ou se, por fôrça dela, o Fisco cancela o lançamento.

\section{$\mathrm{X}$ - DA INSCRIÇÃO DA DÍVIDA FISCAL}

A lei confere a determinados documentos fôrça de sentença, para que possam os respectivos titulares com êles entrar em juizo e pedir a sua execução imediata, a começar pela penhora de bens do devedor. $E^{\prime}$ o que se chama de "ação executiva" ou simplesmente "executivo". E assim o taz a lei fundada em presunção de liquidez do título.

(39) Gomes De Sousa, Curso de Int. ao D. Trib., Rev. de Estudos Fiscais, 1949, página 213 .

(40) Prof. Rubens Gomes DE Sousa, Curso de Introdução ao Direito Tributário, "Rev. de Estudos Fiscais", ano de 1949, pág. 214. 
Entre tais titulos figura também a certidão de dívida ativa da Fazenda Púbiica, extraída de assentamentos dos seus livros, com a qual pode a mesma Fazenda ingressar em juizo pela via executiva, privilégio que lhe é assegurado pela imperiosa necessidade que há de ser facilitado, por meio de uma açãis abreviada e rápida, a cobrança das rendas ou dos créditos das entidades de Direito Público, cujas exigências financeiras precisam ser resguardadas por medidas que impeçam a demora na arrecadação dos seus meios de subsistência. Mas, para que se justifique o procedimento executivo da Fazenda, já o disse um tribunal, baseado em Ribas e leis de 1761 e 1850 , é necessário que a petição seja instruída com certidóes ou documentos incontestáveis, que tornem as mesmas dividas líquidas e certas, pois só assim entre a Fazenda com a sua intenção fundada de fato em escritura pública. Dizia o velho LoBÃo que, "sempre, e de tempos antigos, foi constante no estilo de julgar, que nem ainda pela Real Fazenda tem procedimento executivo as dividas aue, logo no ingresso da execução, se não mostram certas e liquidas emi si mesmas".

Divida liquida e certa - Ensina Pothier, citado por Joño Monteiro: "Uma divida é liquida quando é certo o que se deve e quanto se deve (cum certo certum est an et quantum debeatur"). Na opinião de LAURENT, "a divida não basta ser certa, porque precisa ser liquida; não basta ser liquida, porque precisa ser certa; como condições da exigibilidade, dependem-se recìprocamente". E um dos característicos da liquidez, declara o saudoso magistrado Dr. Cardoso Ribeiro, é a exclusão de qualquer polêmica sôbre o fato, admitida apenas a discussão de direito. ("Revista dos Tribunais", vol. 33. pág. 468).

Já dispunha o Decreto n..$^{9} 985$, de 29 de fevereiro de 1888 , art. $1 .^{\circ}$, que "a via executiva, para cobrança das dividas ativas do Estado, só tem lugar quando estas dividas são liquidas. e certas". E o art. $2 .^{\circ}$ do mesmo decreto definia: "por divida liquida e certa, entende-se a que consiste em soma fixa e determinada".

Esste assunto é regulado atualmente pelo decreto-lei n. 960 , de 17 de dezembro de 1938, que dispõe sôbre a cobrança, por ação executiva, da divida ativa da Fazenda Pública, proveniente de impostos, taxas, contribuições e multas de qualquer natureza; foros, laudêmios e aluguéis; alcances dos responsáveis e reposições (art. $\left.1 .^{\circ}\right)$. Assim define o art. $2 .^{\circ}$ do aludido decreto-lei: "Considera-se liquida e certa quando consistir em quantia fixa e determinada, a divida regularmente inscrita em livro próprio, na repartição fiscal".

Nestas condições, à Fazenda Pública cabe o direito de cobrar executivamente as suas dividas ativas, inclusive as provenientes de tributos, quando prèviamente fixadas e determinadas segundo o processo preconizado pela lei, e regularmente inscritas em livro especial, do qual é extraída a competente certidão, que servirá de base à ação executiva. 


\section{$\mathrm{XI}$ - RESUMO E CONCLUSÃo}

Em resumo, podemos dizer que o crédito fiscal, oriundo de tributos, que GinNNini considera a parte fundamental da relação juridica tributária, $\left({ }^{41}\right)$ se formaliza de acôrdo com os seguintes elementos essenciais:

$\left.1^{\circ}\right)$ ) lei ordinária, permanente, criadora ou agravadora do tributo;

$\left.2 .^{9}\right)$ lei anual orçamentária em que seja registrada aquela lei ordinária;

3. ) ) ocorrência e exteriorização do "fato gerador" do tributo; e

$4 .^{\circ}$ ) lançamento procedido pelo Fisco. Verificados todos êsses elementos do crédito fiscal, surge o direito que tem a Fazenda Pública de cobrar a referida divida ativa, quer amigàvelmente, uma vez que o contribuinte se conforme com o lançamento, quer judicialmente, por meio de ação executiva ou executivo fiscal, fundado em certidão de divida regularmente inscrita em livro próprio da repartição, gozando tal título da presunção legal de certeza e. liquidez.

(41) A. D. Giannini, Il rapporto giuridico d'imposta, Milão, 1937, p. 26. 